J. AMER. SOC. Hort. SCI. 118(6):762-765. 1993.

\title{
Ontogeny and Sulfur Fertility Affect Leaf Sulfur in Short-day Onions
}

\author{
W.M. Randle ${ }^{1}$, M.L. Bussard ${ }^{2}$, and D.F. Warnock ${ }^{3}$ \\ Department of Horticulture, University of Georgia, Athens, GA 30602
}

Additional index words. Allium cepa, flavor, pyruvic acid

\begin{abstract}
Five short-day onion (Allium cepa $\mathbf{L}$.) cultivars grown with high (4.0 meq S/liter) and low (0.1 meq $\mathrm{S} /$ liter) $\mathrm{S}$ fertility were evaluated for ontogenetic changes in leaf $S$ concentration and the association between leaf $S$ concentration and final bulb pungency as reflected by pyruvate formation. Cultivars differed in leaf $S$ concentration at each of eight sampling dates during growth and development, but the pattern of leaf $S$ accumulation among cultivars was similar. Leaf $S$ concentration increased during early plant development while in a nonbulbing photoperiod, but decreased as bulbing progressed to maturity with high and low $\mathbf{S}$ fertility. The decline in leaf $\mathbf{S}$ concentration during bulbing was more severe with low than with high $S$ fertility. Leaves that were left to dry on the mature bulb lost most of their $S$, especially with 0.1 meq $\mathrm{S} /$ liter, a result that could have implications in final bulb flavor intensity. Correlations generally were poor between leaf and final bulb $S$ concentration or pungency.
\end{abstract}

Bulb flavor intensity in onion cultivars depends on their inherent genetic potential (Bajaj et al., 1980; Randle, 1992b; Schwimmer and Guadagni, 1962) and the environment in which they are grown (Bedford, 1984; Lancaster et al., 1988). While specific environmental conditions such as temperature (Platenius and Knott, 1941) and irrigation (Freeman and Mossadeghi, 1973) influence flavor intensity, $\mathrm{S}$ fertility is of particular interest because the primary flavor compounds in onions are S-containing organic compounds (Lancaster and Boland, 1990). Pungency, volatile S, or both in field-grown onions increased in response to increased elemental $\mathrm{S}$ (Kumar and Sahay, 1954), calcium sulfate (Balasubramonian et al., 1978; Paterson, 1979, Smittle, 1984), and ammonium sulfate (Balasubramonian et al., 1978) applications. Varying $\mathrm{SO}_{4}{ }^{2-}$ concentrations in nutrient solutions from 0 to $3 \mathrm{meq} \cdot \mathrm{liter}^{-1}$ increased flavor strength from none to strong, total bulb $\mathrm{S}$ from $0.01 \%$ to $0.50 \%$, and pungency (as measured by pyruvic acid concentration) (Wall and Corgan, 1992) from 0.6 to $9.2 \mathrm{~mol} \cdot \mathrm{ml}^{-1}$ juice in onions grown in sand culture (Freeman and Mossadeghi, 1970). Randle (1992a, 1992b) reported significant cultivar $\times \mathrm{S}$ fertility interactions for foliar and bulb $\mathrm{S}$ concentration, pyruvic acid concentration, and individual water-soluble carbohydrates.

Plants absorb $\mathrm{S}$ mainly as $\mathrm{SO}_{4}{ }^{2-}$, which has little competition for absorption from other elements (Mengel and Kirby, 1982). The uptake mechanism is still debated. Sulfate is mainly translocated acropetally with transpiration. In most plants, basipetal movement is negligible, although $S$ recycling has been demonstrated to occur from old to young leaves in onion (Lancaster et al., 1986). Plantabsorbed sulfate is reduced into organic molecules, of which cysteine is the first stable organic $\mathrm{S}$ compound. The unique flavor of onions comes from the enzymatic hydrolysis of several flavor precursors collectively known as S-alk(en)yl cysteine sulfoxides. The starting point for all flavor precursors is glutathione (Lancaster and Boland, 1990). Labeled S experiments indicate that gamma glutamyl peptides are the first compounds synthesized from glutathione (Lancaster et al., 1989). These peptides subsequently are oxidized and hydrolyzed to the various free flavor precursors,

Received for publication 8 Oct. 1992. Accepted for publication 8 Feb. 1993. The cost of publishing this paper was defrayed in part by the payment of page charges. Under postal regulations, this paper therefore must be hereby marked advertisement solely to indicate this fact.

${ }^{1}$ Assistant professor.

${ }^{2}$ Research technician.

${ }^{3}$ Graduate research assistant. which can comprise up to $4 \%$ of onion dry weight (DW) (Lancaster and Kelley, 1983).

Because of the importance of $S$ in the expression of flavor intensity in onion bulbs, our objectives were to 1) describe the accumulation of $S$ in foliar tissue during onion ontogeny, 2) determine the effect of $\mathrm{S}$ fertility on the accumulation of foliar $\mathrm{S}$ during growth and development, and 3) determine the association between leaf $\mathrm{S}$ concentration at various growth stages and mature bulb pungency as reflected by pyruvate concentration.

\section{Materials and Methods}

Five short-day onion cultivars were used: 'Z238' (Neuman Seed Co., El Centro, Calif.), 'Granex 33' and 'Granex 429' (Asgrow Seed, Kalamazoo, Mich.), 'Rio Bravo' (Rio Colorado Seeds, Yuma, Ariz.), and 'SweetTex' (Ferry Morse Seed Co., Modesto, Calif.). Cultivars were selected based on prior performance at high and low S fertility in Georgia (Randle and Bussard, 1993). Seeds of each cultivar were sown in Fafard no. 3 artificial medium (Fafard Corp., Anderson, S.C.) on 19 Oct. 1990 and transplanted to 0.75 -liter pots containing the same medium on 12 Dec. When the first true leaf emerged (8 Jan. 1991), seedlings were fertilized weekly with half-strength ( 2 meq S/liter) Hoagland's solution (Hoagland and Arnon, 1950) until transplanted. Plants were grown under natural light in a greenhouse, with day and night temperatures set at 28 and $16 \mathrm{C}$, respectively. The experimental design was a split-split plot with three replications. Main plots were $\mathrm{S}$ fertility levels, subplots were tissue sampling dates, and sub-subplots were cultivars. Full-strength Hoagland's solution (4 meq S/liter) was the high $\mathrm{S}$ treatment. The low $\mathrm{S}$ treatment was modified full-strength Hoagland's solution in which $\mathrm{MgCl}$ was substituted with $\mathrm{MgSO}_{4}$ to give $0.1 \mathrm{meq}$ S/liter. After being transplanted, the onions were irrigated twice weekly with the nutrient solutions and supplemented with tap water as needed. Sulfur concentration of the tap water was $<0.05 \mathrm{meq} \cdot \mathrm{liter}^{-1}$. The pots were leached with tap water once a week. For the first two sampling dates, all seedlings were fertilized at the high $\mathrm{S}$ rate.

After seeding, foliar S concentration was determined from leaf blades sampled once a month for 8 months, when the plants reached maturity. The first sampling date was 15 Nov., when all leaves were harvested from 20 seedlings per treatment combination. For the December through May sampling dates, the mostrecently fully expanded leaf was harvested from 10 plants per 
treatment combination. In May, the foliage lodged and the bulbs matured for all cultivars. Water was withheld after the May sampling date and the leaves were left to dry while still attached to the bulb. When the leaves were completely dry in June, all leaves were harvested from 10 plants per treatment combination for the eighth sampling date. The bulbs were harvested, halved basipetally, and one-half of each was analyzed for total S concentration and pungency.

Total tissue $\mathrm{S}$ concentrations were determined using the procedures of Jones and Isaac (1972). Leaf tissues from all sampling dates and bulb tissues were air-dried at $70 \mathrm{C}$ for $72 \mathrm{~h}$ and ground to pass a $0.85 \mathrm{~mm}(20$-mesh) screen. Iron accelerator and magnesium oxide were added to samples that then were ashed at $600 \mathrm{C}$ for $1 \mathrm{~h}$. Samples were cooled and iron and tin accelerators were added and combusted on an $\mathrm{S}$ analyzer (Leco Laboratory Equipment Corp., St. Joseph, Mich.). Combustion gasses were titrated and S was determined against a standard curve generated after every 10 samples. Pungency, as measured by enzymatically formed pyruvic acid, was determined using the methods of Randle and Bussard (1992). Juice was expressed from the onion bulbs using a press and allowed to form pyruvic acid from the enzymatic hydrolysis of flavor precursor molecules. After at least a 10-min incubation, 5\% trichloroacetic acid (TCA) was added to the juice to obtain a final volume of 3 TCA : 1 juice (w/v). One $\mathrm{ml}$ of the juice-TCA mixture was added to $1 \mathrm{ml}$ of $0.0125 \%$ 2,4-dinitrophenylhydrazine in $2 \mathrm{~N}$ $\mathrm{HCl}$ plus $1 \mathrm{ml}$ water and incubated at $37 \mathrm{C}$ for $10 \mathrm{~min}$. Five $\mathrm{ml} 0.6$ $\mathrm{N} \mathrm{NaOH}$ was added before absorbance was read at $420 \mathrm{~nm}$ on a spectrophotometer. Pyruvic acid concentrations were determined against a sodium pyruvate standard curve. Background levels of pyruvic acid were made by first expressing juice into $2.5 \%$ TCA to stop the enzymatic reaction and then following the above procedure. Background levels were subtracted from the total pyruvic acid to give enzymatically formed pyruvic acid.

Data were tested by analysis of variance using SAS's GLM procedures (SAS Institute, Cary, N.C.). Significantly different means within and between $\mathrm{S}$ fertility levels were separated by least significant difference at $P \leq 0.05$. Correlations were calculated between leaf sampling dates and bulb $\mathrm{S}$ concentration and pungency.

\section{Results and Discussion}

Analysis of variance showed highly significant differences $(P$ $\leq 0.01$ ) for all main effects and two-way interactions, while all three-way interactions were nonsignificant. Averaged over sampling date and cultivar, leaf $\mathrm{S}$ was $0.72 \%$ of DW at $4.0 \mathrm{meq} \cdot \operatorname{liter}^{-1}$ and $0.43 \%$ at $0.1 \mathrm{meq} \cdot \operatorname{liter}^{-1}$. Cultivar leafs, averaged over $\mathrm{S}$ fertility and sampling date, ranged from $0.50 \%$ ('Rio Bravo') to $0.59 \% \mathrm{DW}$ ('Granex 33'). These results are similar to leaf S concentrations previously reported for fresh-market onion cultivars (Randle, 1992b). Leaf S concentration was higher at each sampling date with 4.0 meq than with $0.1 \mathrm{meq}$ S/liter when cultivars were averaged (Fig. 1). Leaf $\mathrm{S}$ in November $(0.75 \%$ DW) was higher than typical leaf $\mathrm{S}$, which ranged from $0.10 \%$ to $0.20 \% \mathrm{DW}$ (Thompson et al., 1970). Leaf S declined to $0.55 \% \mathrm{DW}$ in mid-December at transplanting. Leaf $\mathrm{S}$ concentration peaked in mid-January, but the high and low $\mathrm{S}$ treatments begun 4 weeks earlier did not significantly affect leaf $\mathrm{S}$ concentration. During mid-winter, the photoperiod in Georgia (lat. $\approx 34^{\circ} \mathrm{N}$ ) is $\approx 10 \mathrm{~h}$, a period that is below the critical level to stimulate bulbing in short-day onions grown for spring harvest. The first three sampling dates, therefore, represented the period during which onion plants were strictly in the foliar growth phase. Bulbing begins after January in Georgia (Abdallah and Mann, 1963) on plants with

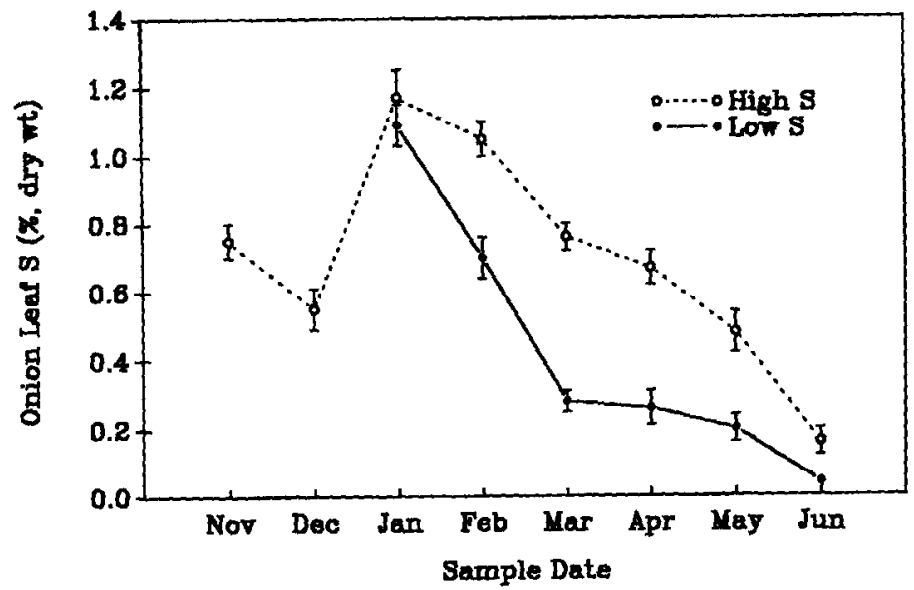

Fig. 1. Onion leaf $S$ concentration ( $\pm 1 \mathrm{SE}$ ) at eight dates during growth and development. Sampling occurred at mid-month. Means are the average of values for five short-day cultivars grown with high $(4.0 \mathrm{meq} S /$ liter $)$ or low $(0.1 \mathrm{meq} S /$ liter) $S$ fertility. The low $S$ treatment did not start until 12 Dec. 1990.

sufficient foliage and, as the photoperiod continues to increase during spring, plants mature. Leaf S concentration decreased from January to February at both $\mathrm{S}$ fertility levels, although the decrease at low $S$ fertility was greater and more rapid (Fig. 1). Leaf $S$ continued to decrease rapidly with low $\mathrm{S}$ fertility to the March sampling date and then leveled off during May as plants matured. The decline in leaf $\mathrm{S}$ concentration at high $\mathrm{S}$ fertility was slower and more uniform during this same period. While $\mathrm{SO}_{4}{ }^{2-}$ basipetal movement is negligible in plants (Mengel and Kirkby, 1982), amino acids are redistributed from leaves to reproductive organs and from old leaves to young leaves. Leaf blades are thought to be the source of $\mathrm{S}$ compounds that accumulate in developing onion bulb scales (Lancaster et al., 1986). These workers noted that flavor precursors increased in bulb scales over time, with a corresponding decrease in the attached leaf blade. Also, some of the precursors were translocated through the basal plate to younger, developing leaf blades or scales. In addition, the pattern of accumulation and loss of flavor precursors depended on the ontogeny of individual leaf blades and scales and the whole plant (Lancaster et al., 1986). In our study, we attempted to limit ontogenetic variability of individual leaf blades by selecting the most recently . fully expanded leaf whose $\mathrm{S}$ concentration, therefore, should reflect differences during whole-plant ontogeny. However, since leaf blade production ceased in April before bulb maturation, the lower leaf S concentration from the May harvest may have been associated with older leaf blades. When the leaves were left to dry while still attached to the bulb after foliar lodging, most of the $\mathrm{S}$ was translocated from the leaves, especially at low $\mathrm{S}$ fertility (Fig. 1). Consequently, June leaf S was $0.16 \% \mathrm{DW}$ at high and $0.04 \%$ DW at low $\mathrm{S}$ fertility.

Competition for $\mathrm{S}$ existed between growing blade tissue and the developing bulb, as indicated by the decreasing leaf $\mathrm{S}$ concentration as bulbing progressed. When onions were grown in sand culture at the Univ. of Georgia under adequate $\left(3.1 \mathrm{meq} \cdot \mathrm{liter}^{-1}\right)$ and minimal (0.1 meq·liter $\left.{ }^{-1}\right) \mathrm{S}$ fertility, leaf number was higher and leaves were larger under minimal $\mathrm{S}$ fertility before bulbing (data not shown). However, once bulbing began and progressed, $\mathrm{S}$ deficiency symptoms appeared as stunted growth and yellowing leaves with green stripes on the plants grown at minimal S fertility, while plants with adequate $S$ fertility grew and produced well. Freeman and Mossadeghi (1970) showed that onions grown in sand culture with $<0.1$ meq $S /$ liter grew minimally and suffered $S$ 
Table 1. Sulfur concentration of leaves sampled at eight dates during growth and development of five onion cultivars grown with high ( $4.0 \mathrm{meq}$ S/liter) or low ( $0.1 \mathrm{meq}$ S/liter) S fertility.

\begin{tabular}{|c|c|c|c|c|c|c|c|c|}
\hline Cultivar & Nov. & Dec. & Jan. & Feb. & Mar. & Apr. & May & June \\
\hline \multicolumn{9}{|c|}{ High $S$} \\
\hline Z238 & 0.74 & 0.63 & 1.18 & 1.08 & 0.75 & 0.69 & 0.46 & 0.16 \\
\hline Granex 33 & 0.83 & 0.58 & 1.31 & 1.04 & 0.72 & 0.66 & 0.50 & 0.20 \\
\hline Granex 429 & 0.71 & 0.49 & 1.11 & 0.97 & 0.77 & 0.68 & 0.56 & 0.17 \\
\hline Rio Bravo & 0.75 & 0.55 & 1.15 & 1.07 & 0.75 & 0.63 & 0.42 & 0.13 \\
\hline SweetTex & 0.73 & 0.49 & 1.15 & 1.08 & 0.82 & 0.71 & 0.46 & 0.16 \\
\hline $\operatorname{LSD}_{0.05}{ }^{2}$ & 0.04 & 0.08 & 0.10 & 0.09 & 0.04 & 0.08 & 0.06 & 0.05 \\
\hline \multicolumn{9}{|c|}{ Low $S$} \\
\hline Z238 & $--{ }^{y}$ & --- & 1.04 & 0.77 & 0.30 & 0.29 & 0.24 & 0.04 \\
\hline Granex 33 & --- & --- & 1.16 & 0.67 & 0.24 & 0.25 & 0.20 & 0.03 \\
\hline Granex 429 & --- &.-- & 1.13 & 0.74 & 0.28 & 0.28 & 0.021 & 0.04 \\
\hline Rio Bravo & -- & -- & 1.13 & 0.62 & 0.28 & 0.22 & 0.15 & 0.03 \\
\hline SweetTex & -- & --- & 1.02 & 0.68 & 0.29 & 0.22 & 0.20 & 0.04 \\
\hline $\operatorname{LSD}_{0.05}{ }^{z}$ & & & 0.10 & 0.09 & 0.04 & 0.08 & 0.06 & 0.05 \\
\hline $\operatorname{LSD}_{0.05}{ }^{x}$ & & & 0.10 & 0.07 & 0.06 & 0.09 & 0.08 & 0.05 \\
\hline
\end{tabular}

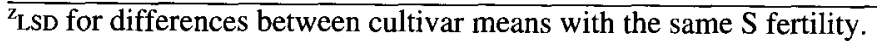

${ }^{y}$ The low $S$ treatment did not commence until the onion seedlings were transplanted in mid-December.

$\mathrm{x}_{\mathrm{LSD}}$ for differences between cultivar means with different $\mathrm{S}$ fertility.

deficiency symptoms. The leaf $\mathrm{S}$ concentration giving $\mathrm{S}$ deficiency symptoms in onions is not known.

While the change in leaf $\mathrm{S}$ concentration over time was similar for all cultivars with high or low S fertility, cultivars differed in leaf $S$ concentration and rank order changed at each sampling date (Table 1). For example, leaf S concentration of 'Granex 33' was significantly higher than those of other cultivars in January with high $\mathrm{S}$ fertility, yet ranked as one of the cultivars with lowest leaf S concentration by March. A similar response for 'Granex 33' was found with low $\mathrm{S}$ fertility for the same dates. Cultivars also responded differentially to $\mathrm{S}$ fertility. For example, 'SweetTex' generally ranked among the cultivars with highest leaf $\mathrm{S}$ concentration with high S fertility, while 'Z238' and 'Granex 429' were among the cultivars with the highest leaf $S$ concentration with low $S$ fertility (Table 1). Similar responses to $S$ fertility were reported for leaf $\mathrm{S}$ concentration in onions of broad genetic background (Randle, 1992b).

Analysis of variance established differences $(P \leq 0.05)$ among $S$ fertility levels and cultivars for mature bulb $S$ concentration and enzymatically formed pyruvic acid. Average bulb S was $0.37 \%$ DW with high and $0.23 \%$ DW with low S fertility. However, significant differences in bulb $\mathrm{S}$ concentration occurred among cultivars with high but not low S fertility (Table 2). Average enzymatically formed pyruvic acid was $4.4 \mu \mathrm{mol} \cdot \mathrm{g}^{-1}$ fresh weight with high and $2.6 \mu \mathrm{mol} \cdot \mathrm{g}^{-1}$ fresh weight with low $\mathrm{S}$ fertility; but, as with bulb $\mathrm{S}$ concentration, differences occurred among cultivars only with high $\mathrm{S}$ fertility (Table 2). Correlations between leaf $\mathrm{S}$ concentration and bulb $\mathrm{S}$ concentration or pyruvic acid concentration at the various sampling dates were generally poor and nonsignificant. The only significant correlations $(P \leq 0.01)$ were between November leaf and mature-bulb $S$ concentration $(r=0.63)$ and between January leaf $S$ concentration and bulb pyruvic acid concentration $[r=(-0.65)]$. Randle (1992b) reported that onions differentially partitioned $\mathrm{S}$ into flavor and nonflavor compounds among cultivars. Therefore, $\mathrm{S}$ found in leaf tissue may not be metabolized to flavor precursor compounds in bulbs.

Sulfur accumulation was high in onion leaf blades during a noninductive bulbing photoperiod. Once exposed to a bulbing photoperiod, leaf $\mathrm{S}$ concentration declined as plants matured. The effect of bulbing on decreasing leaf $\mathrm{S}$ concentration was much
Table 2. Concentrations of $S$ and pyruvic acid in mature bulbs of five onion cultivars grown with high ( 4.0 meq S/liter) or low ( $0.1 \mathrm{meq}$ S/liter) S fertility.

\begin{tabular}{|c|c|c|c|c|}
\hline \multirow[b]{2}{*}{ Cultivar } & \multicolumn{2}{|c|}{$\begin{array}{c}\text { Bulb } S \\
(\% \text { dry wt) }\end{array}$} & \multicolumn{2}{|c|}{$\begin{array}{c}\text { Pyruvic acid } \\
\left(\mu \mathrm{mol} \cdot \mathrm{g}^{-1} \text { fresh wt }\right)\end{array}$} \\
\hline & High S & Low $\mathbf{S}$ & High S & Low $S$ \\
\hline$\overline{\mathrm{Z} 238}$ & 0.36 & 0.24 & 3.5 & 2.8 \\
\hline Granex 33 & 0.40 & 0.24 & 4.7 & 2.3 \\
\hline Granex 429 & 0.34 & 0.22 & 4.6 & 2.6 \\
\hline Rio Bravo & 0.35 & 0.24 & 4.5 & 2.5 \\
\hline SweetTex & 0.38 & 0.22 & 4.9 & 2.7 \\
\hline $\operatorname{LSD}_{0.05}{ }^{\mathrm{z}}$ & \multicolumn{2}{|c|}{0.05} & \multicolumn{2}{|c|}{0.4} \\
\hline $\operatorname{LSD}_{0.05}{ }^{0.05}$ & \multicolumn{2}{|c|}{0.08} & \multicolumn{2}{|c|}{0.5} \\
\hline
\end{tabular}

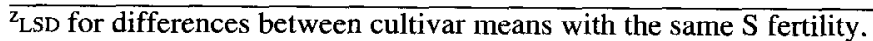
$y_{\text {LSD }}$ for differences between cultivar means with different $S$ fertility.

greater when onions were grown under low than high $\mathrm{S}$ fertility. As a result, care should be taken when growing onions with low $\mathrm{S}$ fertility because, although early onion growth and development may be supported, sufficient $S$ may not be available to sustain growth during active bulbing. Because $\mathrm{S}$ continues to be translocated to the bulb after foliar lodging, flavor could be intensified if the leaves are left to dry while still attached to the bulb before harvest. Conversely, if minimum flavor intensity is desired, the bulb could be harvested and topped soon after foliar lodging. Harvest before foliar lodging may result in decreased flavor intensity (Lancaster et al., 1986) and in decreased bulb quality and storage duration (Aoba, 1963).

\section{Literature Cited}

Abdallah, A. and L.K. Mann. 1963. Bulb development in onion. Hilgardia 35:85-112.

Aoba, T. 1963. On bulb formation and dormancy in onion. VII. Influence of the stage of maturity and the curing of harvested bulbs on bulb formation and sprouting. J. Jpn. Soc. Hort. Sci. 32:224-228.

Bajaj, K.L., G. Kaur, J. Singh, and S.P.S. Gill. 1980. Chemical evaluation of some important varieties of onion (Allium cepa L.) Qualitas Plant. Plant Foods Human Nutr. 30:117-122. 
Balasubramonian, A.S., G.V. Gothandaraman, and K.K. Krishna Moorthy. 1978. Effect of sulphur application on the yield and quality of onion (Allium cepa L.). Agr. Res. J. Kerala 17:138-140.

Bedford, L.V. 1984. Dry matter and pungency tests on British grown onions. J. Natl. Inst. Agr. Bot. 16:58-61.

Freeman, G.G. and N. Mossadeghi. 1970. Effect of sulphate nutrition on flavour components of onion (Allium cepa). J. Sci. Food Agr. 21:610615.

Freeman, G.G. and N. Mossadeghi. 1973. Studies on the relationship between water regime and flavour strength in water cress (Rorippa nasturium-aquaticum [L] Hayek), cabbage (Brassica oleracea var. capitata) and onion (Allium cepa). J. Hort. Sci. 48:365-378.

Hoagland, D.R. and D.I. Arnon. 1950. The water culture method for growing plants without soil. Calif. Agr. Expt. Sta. Circ. 347.

Jones, J.B. and R.A. Isaac. 1972. Determination of sulfur in plant material using a Leco sulfur analyzer. J. Agr. Food Chem. 20:1292-1294.

Kumar K. and R.K. Sahay. 1954. Effect of sulphur fertilization on the pungency of onion. Cur. Sci. 23:368-371.

Lancaster, J.E. and M.J. Boland. 1990. Flavor biochemistry, p. 33-72. In: H.D. Rabinowitch and J.L. Brewster (eds.). Onions and allied crops. vol. 3. CRC Press, Boca Raton, Fla.

Lancaster, J.E. and K.E. Kelley. 1983. Quantitative analysis of the S-alk(en)yl-L-cysteine sulphoxides in onion (Allium cepa L.). J. Sci. Food. Agr. 34:1229-1235.

Lancaster, J.E., B.J. McCallion, and M.L. Shaw. 1986. The dynamics of the flavour precursors, the S-alk(en)yl-L-cysteine sulphoxides, during leaf blade and scale development in the onion (Allium cepa). Physiol. Plant. 66:293-297.

Lancaster, J.E., P.F. Reay, J.D. Mann, W.D. Bennet, and J.R. Sedcole. 1988. Quality in New Zealand-grown onion bulbs-A survey of chemi- cal and physical characteristics. N.Z. J. Expt. Agr. 16:279-285.

Lancaster, J.E., P.H.S. Reynolds, M.L. Shaw, E.M. Dommisse, and J. Munro. 1989. Intracellular localization of the biosynthetic pathway to flavour precursors in onion. Phytochemistry 28:461-464.

Mengel, K. and E.A. Kirkby. 1982. Principles of plant nutrition. 3rd ed. Intl. Potash Inst. Bern, Switzerland. p. 369-386.

Paterson, D.R. 1979. Sulfur fertilization effects on onion yield and pungency. Texas Agr. Expt. Sta. Prog. Rpt. 3551.

Platenius, H. and J.E. Knott. 1941. Factors affecting onion pungency. J. Agr. Res. 62:371-379.

Randle, W.M. 1992a. Sulfur nutrition affects nonstructural water-soluble carbohydrates in onion germplasm. HortScience 27:52-55.

Randle, W.M. 1992b. Onion germplasm interacts with sulfur fertility for plant sulfur utilization and bulb pungency. Euphytica 59:151-156.

Randle, W.M. and M.L. Bussard. 1992. Streamlining onion pungency analyses. HortScience 27: 1116-1117.

Randle, W.M. and M.L. Bussard. 1993. Pungency and sugars of short-day onions as affected by sulfur nutrition. J. Amer. Soc. Hort. Sci. 118:766770 .

Schwimmer, S. and D.G. Guadagni. 1962. Relation between olfactory threshold concentration and pyruvic acid content of onion juice. J. Food Sci. 27:94-97.

Smittle, D.A. 1984. Responses of onions to sulfur and nitrogen fertilization. Univ. Georgia Expt. Sta. Res. Rpt. 455.

Thompson, J.F., I.K. Smith, and D.P Moore. 1970. Sulfur in plant nutrition, p. 80-96. In: O.H. Muth and J.E. Oldfield (eds.). Symposium: Sulfur in nutrition. AVI Publishing, Westport, Conn.

Wall, M.M. and J.N. Corgan. 1992. Relationship between pyruvate analysis and flavor perception for onion pungency determination. HortScience 27:1029-1030. 